Oksana Derkach,

Associate Professor

Taras Shevchenko National University of Kyiv, 90-a, Vasylkivska str., Kyiv, 03022 Ukraine,

ORCID: 0000-0002-0522-6389

ResearcherID: I-3223-2018

\title{
MARKETING MANAGEMENT OF TOURISM ENTERPRISES
}

The article defines the status, features, and tendencies of the development of the domestic tourist market. Features of management of marketing activity of tourist enterprises are presented. As a result of the conducted SWOT-analysis and PESTanalysis, the strategy of tourism enterprise development based on the use of information technologies of CRM «Bitrih24» is proposed.

Keywords: tourism, tourism, marketing strategy of tourism enterprise development, SRM system.

The relevance of the research topic. At the present stage of becoming a market economy of Ukraine, the role of improving the management of marketing activities of domestic tourism enterprises is increasing. An essential element of effective entrepreneurial activity in the information society is the understanding and application of the marketing concept in information technology management.

According to the practice of Ukrainian enterprises, the introduction of marketing is becoming more widespread, however, not all forms of marketing activity management are fully utilized. And this would create the preconditions for ensuring the competitiveness of domestic tourism enterprises, adaptation to the constant changes of the environment and market conditions, the stability of economic conditions. Unlike the heads of tourism enterprises of the developed economies, the heads of domestic tourist enterprises do not yet have sufficient experience in marketing activities using information technologies. Competition in the tourist services market is increasingly fierce, requires scientifically sound management decisions, which makes the research topic relevant.

Formulation of the problem. At the present stage, the modern marketing concept of management of a tourist enterprise based on information technologies, modern progressive methods, and forms of marketing stimulation of market demand for tourist services, the newest approaches to forming a competitive position of domestic tourist enterprises is of considerable interest for both domestic scientists and representatives of the tourism business in a transient environment. 
Analysis of recent researches and publications. The scientific works of many foreign and domestic authors, including I. Ansoff [1], G. Armstrong, [2], S. Harkavenko [6], F. Kotler [7], A. Thompson\& A. Strickland [12], and others. However, insufficient attention has been paid to the peculiarities of enterprise management in the field of tourism through information technology. The purpose of the research is to determine the status and prospects of development of the domestic tourism market, to reveal the features of managing the marketing activity of domestic tourism enterprises based on smart technologies. The validity of the results is ensured by the application of general scientific and specific methods. The theoretical and methodological bases of the study were the basic principles of economic theory, marketing, and strategic management. The following research methods were used in the work: economic and statistical methods - to determine the state and prospects of tourism industry development methods of scientific generalization and systematization - to analyze the strengths and weaknesses, opportunities and threats (SWOT-analysis, PEST-analysis) of the enterprise; graphical method - to present the results and conclusions of the study.

Presenting the main material. The key to a successful tourism business at the beginning of the 21st century is the entry into the market with the creation of a more sophisticated marketing management system with the ability to quickly adapt to the constant chaotic changes in the environment. The experience of developed economies shows that tourism is one of the most profitable types of business activity. At the same time, tourism simultaneously stimulates an increase in the volume of production of goods and the sale of services, activates entrepreneurial activity, and has a positive effect on the diversification of the economy. Integration of the national tourism market into the world tourism space, expansion of international cooperation in the field of travel and tourism, development and implementation of international tourism development programs are further developing, which leads to the growing recognition of Ukraine in the world tourism market. Thus, over the last two years (2017-2019), Ukraine has risen to 10 positions in the Travel and Tourism Competitiveness Index and ranked 78th there. In particular, as the country stabilizes and rebuilds, Ukraine dramatically improved its business environment (from 124 to 103), security (from 127 to 107), international openness (from 78 to 55) and overall infrastructure (from 79 to 73) [15].

The main trends of the tourist services market of Ukraine in 2017-2018 were the reorientation of the domestic consumer to the domestic market (tour domestic flow increased by $30-50 \%$ ), and also demanded tours to countries with visa-free travel or countries with simplified visa regime (in summer period - Turkey, Montenegro, Cyprus, Bulgaria; in winter - Egypt, UAE, Sri Lanka, Thailand) [5, 14]. Table 1 presents the forecast indicators for the development of the tourist services market in Ukraine for the period up to 2026, by the Strategy for the development of tourism and resorts for the period up to 2026 [12, 14]. In early 2020, there is a situation where world tourism is suffering a loss of $\$ 22$ billion due to the spread of the coronavirus 
COVID-2019. Such loss calculations are based on the experience of previous crisis events (SARS or H1N1) $[6,14]$.

Table 1

\section{Forecast indicators of the development of the tourist services market in Ukraine for the period up to 2026 *}

\begin{tabular}{|l|c|c|c|}
\hline \multicolumn{1}{|c|}{ Indicators } & \multicolumn{3}{c|}{ Years } \\
\cline { 2 - 4 } & 2015 & 2022 & 2026 \\
\hline Number of foreign tourists traveling to Ukraine, million people & 12,9 & 25,8 & 32,3 \\
\hline Number of subjects of tourist activity, thousand units & 6,8 & 20,4 & 34 \\
\hline $\begin{array}{l}\text { Amount of revenues to the local budgets from the payment of tourist } \\
\text { tax, million UAH }\end{array}$ & 37,1 & 185,5 & 371 \\
\hline $\begin{array}{l}\text { Amount of consolidated budget revenues (taxes and fees) from the } \\
\text { activity of tourist entities, UAH billion }\end{array}$ & 1,71 & 8,55 & 171 \\
\hline Number of jobs in tourism, thousands of people & 88 & 264 & 440 \\
\hline Number of domestic tourists, thousand people & 357 & 1070 & 1785 \\
\hline Number of sightseers, thousand people & 125,5 & 250,0 & 313,8 \\
\hline
\end{tabular}

Source: Developed by author based on [9].

The epidemic has led to an unprecedented reduction in the cost of travel to other countries. Tour operators even offer such services as «crown virus insurance». Domestic tourism experts believe that such events could be an impetus for the active development of the domestic market in Ukraine.

The director of the Tourism Development Center of Ukraine points out the need for the development of the domestic tourism industry because if the panic in the markets continues, there is unlikely to be many people willing to go on holiday away from home or to book holiday packages for several months in advance. But those who want to travel around Ukraine will be many [5].

One of the tour operators, which has been in the tourist market for more than 20 years and specializes primarily in domestic tourism, is the Kyiv Satellite LLC. The Kyiv Sputnik Travel Company was established on the basis and successor of the Kyiv Sputnik International Bureau of International Youth Tourism in 1997 [10]. It was one of the first in Ukraine to receive a license from the State Tourism Administration of Ukraine for tour operator activity. The goal of the company is to create a competitive, high-level tourism product accessible to all categories of the population. Currently, the company is among the Top 10 tour operators by the number of foreigners served $[10,13]$.

Considering the external and internal factors affecting the tourist services sector, it should be noted that the market development of this service sector is uneven. The main competitors of the Kyiv Satellite Company in the tourist services market are Join UP!, Annex Tour, TPG, TEZ Tour, Coral Travel, PegasTouristik, TUI Ukraine. The matrix of the competitive profile of the Kyiv Satellite Company in the Ukrainian tourist services market is presented (table 2). 


\section{Matrix of the competitive profile «Kyiv Satellite»}

\begin{tabular}{|c|c|c|c|c|c|c|c|c|c|c|c|}
\hline \multirow[b]{2}{*}{$\begin{array}{c}\text { The key } \\
\text { success factors }\end{array}$} & \multirow[b]{2}{*}{ 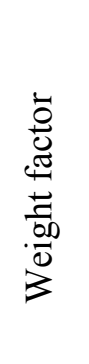 } & \multicolumn{2}{|c|}{ «Join UP!» } & \multicolumn{2}{|c|}{$\begin{array}{l}\text { «Anex } \\
\text { Tour» }\end{array}$} & \multicolumn{2}{|c|}{$\begin{array}{c}\text { «Kyiv } \\
\text { Satellite» }\end{array}$} & \multicolumn{2}{|c|}{$\begin{array}{l}\text { «EZ } \\
\text { Tour» }\end{array}$} & \multicolumn{2}{|c|}{$\begin{array}{l}\text { «Coral } \\
\text { Travel» }\end{array}$} \\
\hline & & 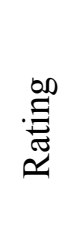 & 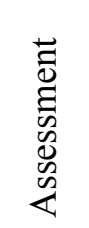 & 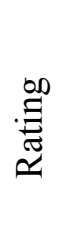 & 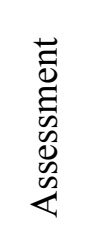 & $\stackrel{\infty}{\Xi}$ & 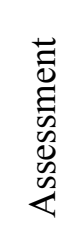 & 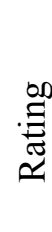 & 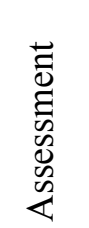 & . & 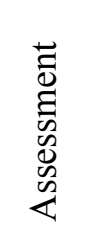 \\
\hline Quality of service & 0,25 & 5 & 1,25 & 5 & 1,25 & 4 & 1,0 & 3 & 0,75 & 4 & 1,0 \\
\hline Price of services & 0,35 & 5 & 1,75 & 3 & 1,05 & 4 & 1,4 & 3 & 1,05 & 5 & 1,75 \\
\hline Market share & 0,23 & 4 & 0,92 & 3 & 0,69 & 1 & 0,23 & 2 & 0,46 & 2 & 0,46 \\
\hline $\begin{array}{l}\text { The level of } \\
\text { development of routes }\end{array}$ & 0,17 & 3 & 0,51 & 5 & 0,85 & 3 & 0,51 & 2 & 0,34 & 2 & 0,34 \\
\hline Overall score & 1 & 17 & 4,43 & 16 & 3,84 & 12 & 3,2 & 10 & 2,6 & 13 & 3,55 \\
\hline
\end{tabular}

Source: Developed by the author $[9,10,11]$.

The matrix of the competitive profile is shown in Fig. 1. The target audience is tourists from the age of 22 to 60 with income from the middle and above the average. Thus, the segmentation of the target audience by the social group is characterized by families; couples without children; youth companies; older people; Customers visiting other cities or countries for work. To evaluate the tourist market in which the «Kyiv Satellite» LLC operates, a PEST analysis was conducted and it was found that the economic, economic and political factors had the greatest degree of influence on the activity of the enterprise.

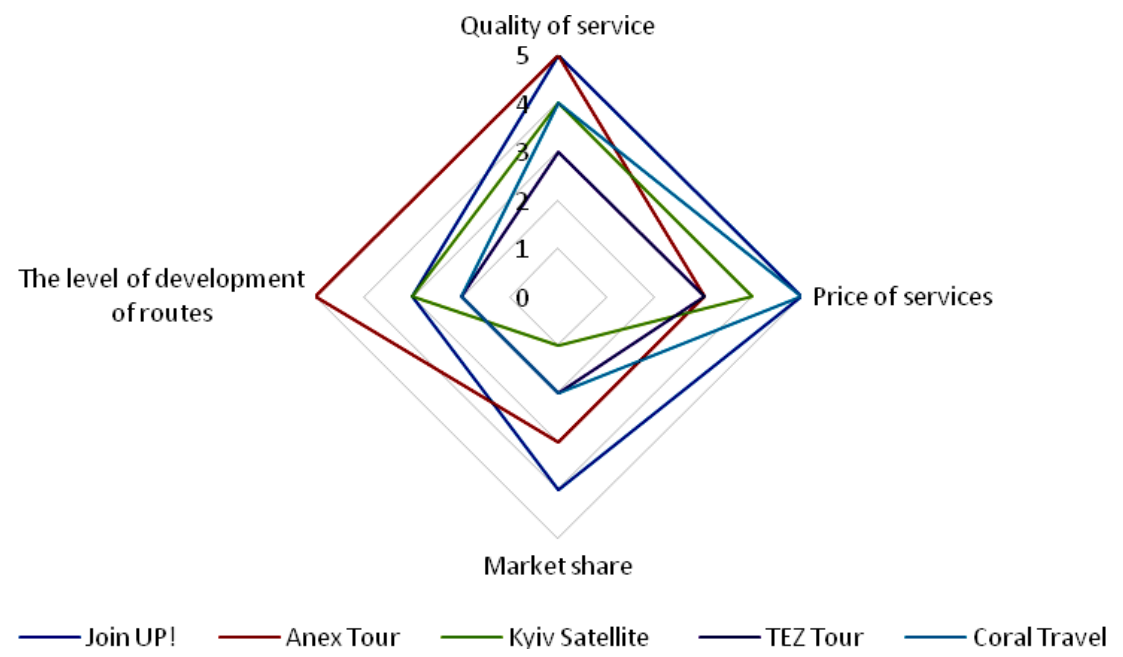

Fig. 1. Competitive Matrix

Source: Developed by author 
The list of factors in the groups was determined by experts, the assessment of the factors was performed on a 5-point scale, the weight was determined by the method of paired comparison of indicators (Table 3 ).

The high level of influence of economic factors is connected with the difficult political situation in the country, which also affected the Ukrainian economy. Accordingly, the most important are the expectations and requests of consumers, possible changes in the supply and demand, currency stability and purchasing power of buyers. The specialization of the enterprise causes a significant influence of sociocultural factors because the customers of tourist services have an interest in the enterprise and its activities, so the highest influence here has the image of the enterprise and communication policy.

As a result of conducting a SWOT-analysis for LLC «Kyiv Satellite», it is determined that the competitive advantages of the enterprise are extensive experience in the market of tourist services, cooperation in the market of tourist services with more than 10 countries, individual approach to each client, highly qualified staff, availability international quality certificates. Therefore, it is advisable for an enterprise to adhere to a combined orientation of competitiveness, namely, demand and resource orientation.

Table 3

\section{PEST-analysis of the «Kiev Satellite»}

\begin{tabular}{|c|c|c|}
\hline $\begin{array}{l}\text { Group } \\
\text { of } \\
\text { factors }\end{array}$ & Factor & Characteristic \\
\hline \multirow{3}{*}{ Eิ: } & Legislation & $\begin{array}{l}\text { In } 2012-2017 \text {, the legal framework has undergone a number of } \\
\text { significant changes, resulting in a significant change in working } \\
\text { conditions for business entities }\end{array}$ \\
\hline & $\begin{array}{l}\text { Regulation and } \\
\text { restrictions on } \\
\text { international } \\
\text { trade }\end{array}$ & $\begin{array}{l}\text { WTO membership and association with the EU are a deterrent } \\
\text { to any radical change, so no major change is expected. There is } \\
\text { also no change for the business in question }\end{array}$ \\
\hline & $\begin{array}{l}\text { State regulation } \\
\text { of competition }\end{array}$ & State regulation is not sufficiently implemented in the industry \\
\hline 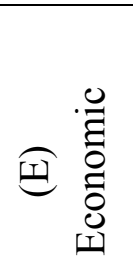 & $\begin{array}{l}\text { Economic } \\
\text { growth }\end{array}$ & $\begin{array}{l}\text { The economy has already passed the lower point of decline. } \\
\text { Thus, it is possible to predict a steady increase in the demand } \\
\text { for services in the next } 3-5 \text { years. This means that entering the } \\
\text { market at the moment and gradually expanding its presence is } \\
\text { extremely favorable }\end{array}$ \\
\hline
\end{tabular}




\begin{tabular}{|c|c|c|}
\hline $\begin{array}{l}\text { Group } \\
\text { of } \\
\text { factors }\end{array}$ & Factor & Characteristic \\
\hline & Taxation & $\begin{array}{l}\text { No radical changes in the tax policy for } 2018-2019 \text {, which can } \\
\text { adversely affect the work of the company is not expected }\end{array}$ \\
\hline \multirow{3}{*}{$\widetilde{D} \cdot \frac{\pi}{0}$} & Education & $\begin{array}{l}\text { The general tendency to decrease the level of education in the } \\
\text { country }\end{array}$ \\
\hline & Demographics & $\begin{array}{l}\text { An increase in the number of people in retirement and pre- } \\
\text { retirement ages, and a decline in population, is likely to force } \\
\text { the state to increase tax pressure on wages. This factor is global } \\
\text { for the entire post-Soviet space and Europe }\end{array}$ \\
\hline & $\begin{array}{l}\text { Distribution of } \\
\text { income }\end{array}$ & $\begin{array}{l}\text { The high level of corruption, which has increased the pressure } \\
\text { on small and medium-sized businesses, can lead to serious } \\
\text { delamination of business structures, the emergence of mergers } \\
\text { and concentration. As a result, the chosen focus on big and } \\
\text { medium business is justified }\end{array}$ \\
\hline$\widehat{E} \frac{\substack{\tilde{E} \\
00}}{\frac{0}{0}}$ & $\begin{array}{l}\text { Dynamics of } \\
\text { development } \\
\text { and technologies }\end{array}$ & $\begin{array}{l}\text { The development of technologies and their increasing } \\
\text { availability imply the inevitable complication of the processes } \\
\text { of their effective application. Accordingly, there is a demand } \\
\text { for professionals able to organize their effective use within the } \\
\text { existing business. Combined with the factors described earlier, } \\
\text { this trend has a long-term trend and is favorable }\end{array}$ \\
\hline
\end{tabular}

Source: Developed by author.

The research revealed that the most appropriate strategy to be followed by «Kyiv Satellite» LLC is a development strategy. This strategy is based on improving the quality of tourist services and the introduction of modern IT technologies on a Smart basis, in particular CRM-system. This technology will extend the concept of sales of the «Kyiv Satellite» Company from individual action to a continuous process that includes every step from marketing, customer qualification, proposal management, sales management, and ending with ordering, providing tourist services or service, and resale.

The advantages of using CRM-system in LLC «Kyiv Satellite» will be to increase the competitiveness of the company, increase profits, attract new customers and retain an existing customer base. In addition, an online view of the statistical information will be available to assess the likelihood of entering into an agreement and to predict the rate of passage of customers from the «desire» state to the «purchase» status of tourist products/services. This will effectively manage the cash flow of the 
enterprise. Since the number of company personnel is 30 people, it is advisable to stop choosing Bitrix24 software with the command tariff for the implementation of the CRM-system (Table 4).

Table 4

Software CRM»Bitrix24»

\begin{tabular}{|l|c|c|c|}
\hline \multirow{2}{*}{} & \multicolumn{3}{|c|}{ Tariff } \\
\cline { 2 - 4 } & Project+ & Team & Company \\
\hline Price, UAH / month & 499 & 2200 & 4400 \\
\hline Users & Unlimited & Unlimited & Unlimited \\
\hline Business users & 24 & 50 & Unlimited \\
\hline A place in the cloud & $24 Г Б$ & $100 \mathrm{~GB}$ & Unlimited \\
\hline
\end{tabular}

Source: Developed by author based on [2, 3].

The main advantages of the Bitrix 24 CRM system are simplicity of the interface; «Cloud» disk for document processing and data analysis; a wide range of marketing communications; adaptability with other popular services; attractive price. For the implementation of the project on implementation of the CRM-system «Bistriks24» in LLC «Kyiv Satellite», it is necessary to spend 36.5 thousand UAH. The calculations revealed that the project is feasible since investment feasibility $(\mathrm{NPV}=\mathrm{UAH} 10.09$ thousand $)$ and profitability index $(\mathrm{RI}=1.27)$ are positive.

The application of the CRM system in the management of enterprise marketing, in addition to economic feasibility, is to increase the competitiveness of the company and increase profits, automate sales and marketing campaigns, simplify customer relations, digitization, and improve employee performance.

Conclusion. Managing the marketing activities of domestic tourism enterprises is a very topical issue. In the conditions of informatization of society, the use of modern information technologies is a key aspect of developing a marketing strategy for the development of a tourism enterprise. The key functions of implementation of CRM-system at the enterprise will be the realization of technology of sale of tourist products to different groups, management of stages and stages of the sale, mechanism of preparation of commercial offers, mechanism of operational management, analysis of sales cycle, development of individual marketing campaigns,»cloud» storage of information.

\section{REFERENCES}

1. Ansoff, I. (1999) Novaja korporativnaja strategija. Piter, Sankt-Peterburg, Russia.

2. Armstrong, G. (2019).Osnovyi marketinga. M. : Vilyams. 
3. Bezuhlyi, I.V. (2019). Suchasni tendentsii rozvytku innovatsii v turyzmi. Infrastruktura rynku, №. 30, pp. 136-141. Retrieved from http://www.market-infr. od.ua/journals/2019/30_2019_ukr/7.pdf

4. CRM systems in the tourism business. Retrieved from http:// tursite.org/ modules/informacionnye-tehnologii-v-turizme/crm-sistemy-v-turisticheskom-bizneseю

5. Epidemiia koronavirusu u sviti dala shans dlia rozvytku turyzmu v Ukraini. Retrieved from http://tvoemisto.tv/news/epidemiya_koronavirusu_chas_na_deshevi_ podorozhi_i_shans_dlya_rozvytku_vnutrishnogo_turyzmu_107095.html

6. Harkavenko, S. (2002). Marketynh. K.Libra

7. Kotler, F. (2019). Osnovy marketynha. M. : Dyalektyka.

8. Kotler, P. Bowen, J. \&Makens, J. (2017), Marketing for hospitality tourism, 6th ed. London, UK.

9. Rozporiadzhennia kabinetu Ministriv Ukrainy «Pro skhvalennia Stratehii rozvytku turyzmu ta kurortiv na period do 2026 roku» 16.03.2017 roku № 168-p (2017, March). Retrieved from https://www.kmu.gov.ua/npas/249826501

10. The official site of LLC «Kiev Satellite» Retrieved fromhttps://youcontrol. com.ua/ru/catalog/company_details/25388117/

11. The official site of State Statistics Service of Ukraine (2019), Retrieved from http://www.ukrstat.gov.ua/

12. Thompson, A. A.,\& Strickland, A. J. (2009). Strategicheskii menedgment. Moskva: Willyams.

13. Tourism in Ukraine: Where do you go the most and which areas need to be developed». Retrieved from http://expres.ua/news /2017/10/05/265404-turyzmukrayini-kudy-yidut-naybilshe-napryamypotribno-rozvyvaty

14. Tourism losses from coronavirus are estimated at 22 billion dollars. Retrieved from https://www.epravda.com.ua/rus/news/2020/02/28/657591

15. UITT Tourism Exhibition: «UKRAINE - Travel and Tourism». Retrieved from https://www.uitt-kiev.com/uk-UA/press/news/3177.aspx 